\title{
Fertilization and Early Embryonic Development in Heifers and Lactating Cows in Summer and Lactating and Dry Cows in Winter
}

\author{
R. Sartori, ${ }^{\star}$ R. Sartor-Bergfelt, $\uparrow$ S. A. Mertens, ${ }^{*}$ \\ J. N. Guenther, ${ }^{\star}$ J. J. Parrish, $\dagger$ and M. C. Wiltbank* \\ *Department of Dairy Science and \\ †Department of Animal Sciences, \\ University of Wisconsin, Madison 53706
}

\begin{abstract}
Abbreviation key: $\mathbf{C L}=$ corpus luteum or corpora lutea, $\mathbf{C R}=$ conception rate, $\mathbf{P}_{\mathbf{4}}=$ progesterone, UFO $=$ unfertilized oocyte $(\mathrm{s})$.
\end{abstract}

\section{INTRODUCTION}

There are many types of data consistent with a decrease in reproductive efficiency occurring in high-producing lactating dairy cows (Royal et al., 2000a,b; Lucy, 2001; Washburn et al., 2002). For example, conception rates (CR) for lactating dairy cows in scientific manuscripts were $>50 \%$ in the 1940s and 1950s (Barrett and Casida, 1946; Casida, 1961; Mares et al., 1961), 50\% in the 1970s (Macmillan and Watson, 1975; Spalding et al., 1975; Washburn et al., 2002), and $40 \%$ or less in the 1990s (Schmitt et al., 1996; Pursley et al., 1997a; Butler, 1998; Washburn et al., 2002). Although a relationship between milk production and fertility is still controversial, the milk production per cow increased substantially from the 1950s to the 1990s (2600 to $8000 \mathrm{~kg} /$ lactation [USDA, 1978; USDA, 2001]), suggesting a possible association between milk production and CR (Silvia, 1998). Of particular importance, CR in heifers has remained at about $70 \%$ during this time (Foote, 1975; Spalding et al., 1975; Pursley et al., 1997b) and within-herd evaluations consistently show dramatically lower CR in lactating cows than in heifers (Pursley et al., 1997b; Sartori and Wiltbank, personal observations). One important study that compared milk production and reproduction was done by Faust et al. (1988), in which first-lactation cows were grouped by first-lactation milk yield and found to have much lower CR at first service in high-producing than lower-producing cows $(<7250 \mathrm{~kg} /$ lactation $=56.5 \% ; 7250$ to $9750 \mathrm{~kg}=$ $37.8 \%$; $>9750 \mathrm{~kg}=17.4 \%)$. Comparisons of reproductive traits in lactating and nonlactating dairy cows (De La Sota et al., 1993; Beam, 1995) have not yet allowed definition of physiological mechanisms involved in decreased reproductive efficiency associated with high milk production.

One approach to understand fertility has been to flush embryos at given stages after breeding to deter-

Received November 6, 2001.

Accepted May 3, 2002.

Corresponding author: M. C. Wiltbank; e-mail: Wiltbank@calshp. cals.wisc.edu. 
mine fertilization failure and timing of embryonic mortality. An early study of dairy cattle (Boyd et al., 1969) found an $85 \%$ fertilization rate and a $70 \%$ embryonic survival to $\mathrm{d} 26$. In beef cattle it has been determined that fertilization rate is very high $(>90 \%)$, and most pregnancy losses have occurred by d 13 (Diskin and Sreenan, 1980). We have found only two studies that flushed early embryos from normally ovulating, highproducing, lactating dairy cows (Wiebold, 1988; Ryan et al., 1993). Wiebold (1988) collected 25 embryos from 23 lactating dairy cows and found that all ova were fertilized, with 12 normal and 13 abnormal embryos. Ryan et al. (1993) flushed embryos during the hot or cool time of year and found no effect of high environmental temperature on fertilization failure (17.6 vs. $20.5 \%)$ or percentage of viable embryos on d 6 or 7 (58.5 vs. 51.6\%) but did find decreased percentage of viable embryos on d 13 or 14 (27.1 vs. $59.5 \%)$. None of these previous studies directly compared lactating and nonlactating female dairy cattle for fertilization rate and early embryonic development. Therefore, two experiments were designed to compare lactating and nonlactating cattle for fertilization rate after AI with high-fertility semen. Early embryonic development was assessed by embryo quality score and number of embryonic cells. In the first experiment, high-producing lactating Holstein cows were compared to nulliparous Holstein heifers during the summer. The second experiment was done during cool weather and compared lactating to dry cows of similar weight and age. The overall hypothesis of these studies was that high-producing dairy cows would have decreased early embryonic development but not decreased fertilization rate compared to nonlactating females either in the presence or absence of heat stress.

\section{MATERIALS AND METHODS}

\section{Experiment 1}

Animals. Lactating Holstein cows ( $\mathrm{n}=27$; seven primiparous and 20 multiparous; $97.3 \pm 4.1 \mathrm{~d}$ postpartum [mean \pm SEM; ranging from 70 to 140]; daily milk production of $40.0 \pm 1.5 \mathrm{~kg}$ [ranging from 25.9 to 52.2 ]; 4.0 $\pm 0.3 \mathrm{yr}$ old [ranging from 2.0 to 9.0]) and nulliparous Holstein heifers ( $\mathrm{n}=28 ; 11$ to 17 mo old) were used at the University of Wisconsin, Madison. Cows were housed in a stanchion barn at the Dairy Cattle Research Center in Madison. Heifers were housed on dirt lots with an indoor feeding area containing headlocks at the heifer facility in Arlington, WI. Cows were milked twice daily and were fed TMR that consisted of corn silage and alfalfa silage as forage and corn-soybean meal based concentrate. The TMR contained $18.0 \% \mathrm{CP}$ and $1.65 \mathrm{Mcal} / \mathrm{kg}$ of $\mathrm{NE}_{\mathrm{L}}$ (percentage of $\mathrm{DM}$ ). Heifers were fed a TMR consisting of $70 \%$ alfalfa silage and $30 \%$ corn silage $\left(16.8 \% \mathrm{CP}\right.$ and $1.36 \mathrm{Mcal} / \mathrm{kg}$ of $\mathrm{NE}_{\mathrm{L}}$ ). Both groups had free access to water. Cows and heifers had a BCS (scale from 1 to 5 ) of $3.2 \pm 0.1$ and $3.7 \pm 0.1$, respectively at the beginning of the experiment. Cows but not heifers were injected s.c. with $500 \mathrm{mg}$ of recombinant bST (Posilac; Monsanto Co., St. Louis, MO) at 12-d intervals. Rectal temperature was measured daily from heifers ( $\mathrm{n}=662$ observations) and cows $(\mathrm{n}=596$ observations) from the day of AI to the day of embryo collection. This experiment was done during the summer of 1999, and daily ambient temperature and humidity were recorded at both locations.

Reproductive management. Cows were visually observed for signs of estrus at 7 a.m. and 7 p.m. for 20 min with the aid of a cow that was androgenized by placing eight Synovex H implants (Fort Dodge Laboratories Inc., Fort Dodge, IA) in the ear. In addition, each cow was fitted with a pressure-activated heat mount detector (Kamar; Kamar Inc., Steamboat Springs, CO) that was checked twice daily after milking. For heifers, the only criterion used for determination of estrous behavior was the presence of an activated Kamar, that was checked once daily (9 a.m.). During this period, the ovaries of cows and heifers were scanned by daily ultrasound (Aloka 500-V with a 7.5 MHz linear-array transducer; Corometrics Medical Systems Inc., Wallingford, CT) to observe corpus luteum (CL) development and regression, identify the ovulatory follicle(s), and confirm ovulation.

Cows were classified as anovulatory if they did not have a CL during an 11-d period of ultrasound evaluation ( $\mathrm{n}=9$ lactating cows and 0 heifers). These cows were treated with an i.m. injection of GnRH (100 $\mu \mathrm{g}$ of Cystorelin; Merial Limited, Iselin, NJ). Cows that failed to ovulate to this first injection $(n=2)$ were treated with $\mathrm{GnRH}$ again $7 \mathrm{~d}$ later. After ovulation to the $\mathrm{GnRH}$, all previously anovulatory cows went through a complete luteal phase and then were checked for estrus and inseminated after detection of estrus. All ovulatory females (CL confirmed) were not treated with any hormones before the first AI. Thus, all cows and heifers were inseminated only after demonstration of a natural estrus.

Cows and heifers were inseminated at a specific time of the day (cows at 3 p.m., and heifers at 1 p.m.) using the following rule: if Kamar was activated or animals showed primary or secondary signs of estrus in the morning of the AI day, they were inseminated on the same day, but if estrus was detected in the afternoon, the animals were inseminated on the following day. Daily ultrasound was always done just before AI in cows ( 2 p.m.) and heifers ( n noon). Any animals that 
received AI the previous day but had not yet ovulated at time of ultrasound received a second AI $(22 / 79=$ $27.8 \%$ of heifers, and $12 / 68=17.6 \%$ of cows). All cows and heifers were inseminated by the same technician, using frozen-thawed semen from a straw containing 0.5 $\mathrm{ml}$ of combined semen from four high fertility bulls selected for high nonreturn rates (equal number of sperm added from each bull with postthaw motility of 70\%; ABS Global, De Forest, WI).

Embryo collection and evaluation and resynchronization of animals. Day 0 was defined as the day before ovulation on which the dominant follicle(s) was last detected by ultrasound. On d 6 ( $5 \mathrm{~d}$ after ovulation), embryos were recovered using a standard nonsurgical uterine flushing technique (Elsden et al., 1976; Rowe et al., 1976) with sterile Dulbecco's PBS + 0.4\% BSA (Fraction V; Sigma, St. Louis, MO). Embryos were evaluated for fertilization, and embryo quality was graded $(1=$ excellent, $2=$ good, $3=$ fair, $4=$ poor, and 5 = degenerate), similar to Ahmad et al. (1995). Numbers of accessory sperm were evaluated by staining the embryo with $2.5 \mu \mathrm{g} / \mathrm{ml}$ Hoechst 33342 (Molecular Probes, Inc., Eugene, OR) and counting accessory sperm nuclei in the zona pellucida with epifluorescence microscopy (365 $\mathrm{nm}$ excitation, $>400 \mathrm{~nm}$ emission). The zona pellucida was next dissolved by adding $20 \mu \mathrm{l}$ of $0.1 \%$ Tween-20 (Sigma, St. Louis, MO) in $0.01 \mathrm{~N} \mathrm{HCl}$ for $2 \mathrm{~min}$. This allowed the blastomeres to spread on the slide. The blastomeres were then stained with 2.5 $\mu \mathrm{g} / \mathrm{ml}$ Hoechst 33342 , and embryonic cell nuclei were counted with epifluorescence microscopy. Unfertilized oocytes (UFO) were designated when there were no signs of cleavage and each had only one fluorescent nucleus when viewed under the microscope.

After collection of embryos, CL were regressed by i.m. injections of a $\mathrm{PGF}_{2 \alpha}$ analog ([Estrumate; Bayer Corporation, Shawnee Mission, KS] $500 \mu \mathrm{g}, 1 \mathrm{~d}$ after flushing and $250 \mu \mathrm{g} 2 \mathrm{~d}$ after). Cows and heifers were observed for estrus and were re-inseminated as described above. This procedure (detection of estrus, AI, collection of embryos, and $\mathrm{PGF}_{2 \alpha}$ injection) was performed two or three times in each female. Ovarian ultrasonography was performed on the day of embryo collection, and daily until next ovulation.

\section{Experiment 2}

Animals. Lactating Holstein cows ( $\mathrm{n}=27$; four primiparous and 23 multiparous; $46.4 \pm 1.6 \mathrm{~d}$ postpartum [ranging from 37 to 60]; daily milk production of 45.9 $\pm 1.4 \mathrm{~kg}$ [ranging from 29.3 to $61.2 \mathrm{~kg}$ ] $44.3 \pm 0.4 \mathrm{yr}$ old [ranging from 2 to 8]) and nonpregnant nonlactating (dry) Holstein cows $(\mathrm{n}=26 ; 4.9 \pm 0.3$ yr old [ranging from 3 to 8]) were used at the Dairy Cattle Research
Center at the University of Wisconsin, Madison during the winter of 1999-2000. Dry cows had previously been culled primarily due to reproductive problems $(17 / 26=$ $65 \%$ ), with all of these cows having multiple services during the previous lactation (average of 6.7 services). Other reasons for culling were low milk production (n $=2)$, mastitis $(n=2)$, displaced abomasum $(n=1)$, or unknown $(n=4)$. Lactating and dry cows were housed in stanchion barns. Lactating cows were kept indoors constantly except during milking and heat detection. Dry cows were kept outdoors during the day and indoors during the night. Lactating cows were milked twice daily and were fed a TMR similar to experiment 1 (18.8\% CP and $1.69 \mathrm{Mcal} / \mathrm{kg}$ of $\mathrm{NE}_{\mathrm{L}}$ ). Dry cows received the refusals from the lactating cows during the day and received alfalfa hay free-choice during the night. Both groups had free access to water. At the beginning of the experiment, lactating and dry cows had a BCS of $2.9 \pm 0.1$ and $3.3 \pm 0.1$, respectively. The average BW at the end of the experiment was $620.6 \pm 15.1$ and 734.1 $\pm 17.3 \mathrm{~kg}$ for lactating and dry cows, respectively. Cows did not receive rbST in experiment 2 . Rectal temperature was measured for a subset of cows from both groups on the day of embryo collection.

Reproductive management. At the beginning of experiment 2, all cows received an i.m. GnRH injection $(100 \mu \mathrm{g})$ followed $7 \mathrm{~d}$ later by $25 \mathrm{mg}$ of i.m. $\mathrm{PGF}_{2 \alpha}$ (ProstaMate; Phoenix Pharmaceutical Inc., St. Joseph, MO). Cows were observed for estrus twice daily (20 min each time) using an androgenized cow. The cows were also fitted with a pressure-activated heat mount detector (Kamar). Cows showing standing estrus or an activated Kamar were inseminated with the same semen and by the same person as in experiment 1 . Ovaries were scanned by ultrasonography, as described for experiment 1 , including an examination at $23 \mathrm{~h}$ after AI in cows that had been inseminated. Artificial insemination was repeated $24 \mathrm{~h}$ after the first AI if ovulation had not yet occurred by the time of ultrasonography (4/ $62=6.5 \%$ of dry cows and $15 / 57=26.3 \%$ of lactating cows).

Cows were classified as anovulatory if they failed to ovulate during a 7-d period after $\mathrm{PGF}_{2 \alpha}$ injection $(\mathrm{n}=$ 6 lactating and 12 dry cows). Anovulatory cows were treated with an i.m. GnRH $(100 \mu \mathrm{g})$ injection. If they ovulated to this GnRH treatment they were given 25 mg $\mathrm{PGF}_{2 \alpha}$ at $\mathrm{d} 7$, observed for estrus, and inseminated using the a.m./p.m. rule. If they again failed to ovulate ( $\mathrm{n}=4$ dry cows) they were given another GnRH treatment on $\mathrm{d} 14$ followed $7 \mathrm{~d}$ later by a $\mathrm{PGF}_{2 \alpha}$ treatment and breeding. These cows were inseminated using the same procedures described above, following behavioral estrus. 
Embryo collection and evaluation and resynchronization of animals. The embryo collection and evaluation procedures, as well as the ultrasonography were similar to experiment 1 , with some minor modifications, as follows. In experiment 1, only the tip of the uterine horn ipsilateral to the CL was flushed, using an average of $200 \mathrm{ml}$ of PBS + BSA solution. At the suggestion of R. G. Saacke (Virginia Polytechnic Institute), we flushed the entire uterine horn ipsilateral to the CL with 500 to $1000 \mathrm{ml}$ of PBS + heat-inactivated Fetal Calf Serum (1\%, Sigma, St. Louis, MO) in experiment $2 . \mathrm{PGF}_{2 \alpha}$ was only administered once on the day following embryo collection instead of the two treatments with $\mathrm{PGF}_{2 \alpha}$ in experiment 1 . As in experiment 1 , detection of estrus, AI, collection of embryos, and $\mathrm{PGF}_{2 \alpha}$ injection were performed two or three times in each cow.

In order to evaluate the potential associations between serum progesterone $\left(\mathbf{P}_{4}\right)$ concentration and early embryonic development, blood samples were collected on $\mathrm{d} 7$ of the estrous cycle. Information on blood sampling and methods for analyzing circulating $\mathrm{P}_{4}$ are provided in a companion paper (Sartori et al., 2002).

\section{Statistical Analyses}

Cow was used as the experimental unit for analysis of embryo quality and accessory sperm number by averaging the values for all collections. This helped to minimize any confounding effects from flushing each female more than one time or from recovery of two or more embryos at the same collection. There was no effect of one versus two inseminations on accessory sperm number $(P=0.62)$, and data from those cows were combined in the analysis. The Mantel-Haenszel Chi-square analysis was used to evaluate binomial variables, such as UFO/embryo recovery rates, percentage of fertilized embryos, percentage of flushings with at least one viable embryo (grades 1, 2, or 3), and percentage of viable embryos. Student's $t$-test was used for continuous variables, such as ambient and body temperatures and humidity. On the basis of the empirical skewed distribution, differences between groups for embryo quality, number of nuclei/embryo, and number of accessory sperm were analyzed by the nonparametric procedure of Wilcoxon's two-sample test (Zar, 1996). Analysis of body temperature as a function of ambient temperature was performed by using a random coefficient model for repeated measurements (Littell et al., 1996), with different intercepts and slopes for each group of females (cows and heifers). The analysis was performed using the MIXED procedure of SAS (Littell et al., 1996). The potential associations between circulating $\mathrm{P}_{4}$ and embryo quality or number of nuclei per embryo were ana- lyzed only for data collected in experiment 2. Pearson and Spearman correlation tests were performed using data from all cows or analyzing data separately from lactating and dry cows. In addition, cows were divided by embryo quality score, and differences in serum $\mathrm{P}_{4}$ concentrations were compared using one-way ANOVA.

\section{RESULTS}

\section{Experiment 1}

Ambient temperatures, humidity, and body temperatures. There was substantial variation in daily ambient temperature and humidity at both experimental locations during experiment 1 (Table 1). Daily temperatures ranged from 7.2 to $37.7^{\circ} \mathrm{C}$, and humidity ranged from 30 to $95 \%$. The average maximum and minimum ambient temperatures were higher and lower, respectively, at the heifer facility than at the lactating cow stanchion barn (Table 1). In spite of the higher maximum ambient temperature, heifers had lower $(P<0.05)$ body temperature $(38.7 \pm 0.01$; ranging from 37.7 to $\left.40.2^{\circ} \mathrm{C}\right)$, than lactating cows $(39.3 \pm 0.03$; ranging from 38.0 to $41.7^{\circ} \mathrm{C}$ ). Regression equations of body temperature (for either heifers or cows) compared to ambient temperature between 20 and $33^{\circ} \mathrm{C}$ (at the time of rectal temperature evaluation) were estimated using temperature data collected from heifers $(n=654$ observations) and cows ( $\mathrm{n}=575$ observations). As shown in Figure 1, lactating cows had a greater $(P<0.05)$ increase in body temperature in response to increases in environmental temperature than was observed in heifers.

Embryoloocyte collection and evaluation. There were 79 uterine flushings performed in heifers and 68 in lactating cows. The percentage of flushings with one or more embryos recovered per collection (recovery rate per flushing) was 40.5\% (32 of 79 flushings) for heifers and $45.6 \%$ (31 of 68 flushings) for cows $(P>0.05)$. As previously described in Wiltbank et al. (2000), lactating cows were more likely to ovulate more than one follicle after estrus (41 of 68 ovulations) than heifers ( 1 of 79 ovulations); therefore, more than one embryo/oocyte was recovered in some single flushes. Recovery rate per CL $(<40 \%)$ did not differ $(P>0.05)$ between groups (Table 2). Despite the high ambient temperatures observed on some of the days during experiment 1, 100\% of the structures recovered from the heifers on $d 6$ were fertilized (Table 2). On the other hand, from 38 structures recovered from cows, only $55.3 \%$ were considered fertilized (two or more cells), and $44.7 \%$ were considered UFO (Table 2).

Average quality of the embryos recovered from heifers was better than embryos from cows (Table 2). Figure 2 shows the distribution of embryo quality for heifers 
Table 1. Results (means \pm SEM [range]) for daily ambient temperature and humidity recorded for the housing locations of lactating cows in Madison (6/9/1999 to 9/15/1999) and heifers in Arlington, WI (6/9/99 to $8 / 14 / 99$ ) during experiment 1.

\begin{tabular}{lll}
\hline & Heifers & Lactating cows \\
\hline Maximum temperature, ${ }^{\circ} \mathrm{C}$ & $29.3 \pm 0.5^{\mathrm{b}}[21.6$ to 37.7$]$ & $27.9 \pm 0.4^{\mathrm{a}}[19.9$ to 36.2$]$ \\
Minimum temperature, ${ }^{\circ} \mathrm{C}$ & $17.5 \pm 0.5^{\mathrm{a}}[7.2$ to 24.2$]$ & $19.7 \pm 0.4^{\mathrm{b}}[12.2$ to 27.6$]$ \\
Humidity, $\%$ & $62.0 \pm 2.0[32.0$ to 95.0$]$ & $59.3 \pm 1.6$ [30.0 to 91.0] \\
\hline
\end{tabular}

${ }^{\mathrm{a}, \mathrm{b}}$ Different within each row; $P<0.05$.

and lactating cows in experiment 1 . A higher percentage of embryos were degenerate (grade 5) from cows $(62 \%)$ than from heifers (6\%). Embryos from heifers had a greater number of nuclei per embryo than embryos from cows (Table 2). This difference in nuclei number was primarily due to differences in percentage of viable (transferable) embryos (grades 1, 2, or 3) because nuclei number in viable embryos did not differ between heifers and lactating cows (Table 2). The percentage of flushings with at least one viable embryo was greater for heifers than for lactating cows (Table 2). The percentage of viable embryos, when UFO were not considered and all embryos were combined, was also higher $(P<0.05)$ for heifers (Table 2).

Numbers of accessory sperm were evaluated in all structures (embryos and UFO) recovered from heifers and cows in order to assess a possible contribution of the semen to the lower fertility in cows. Lactating cows had more $(P<0.05)$ accessory sperm in the embryos

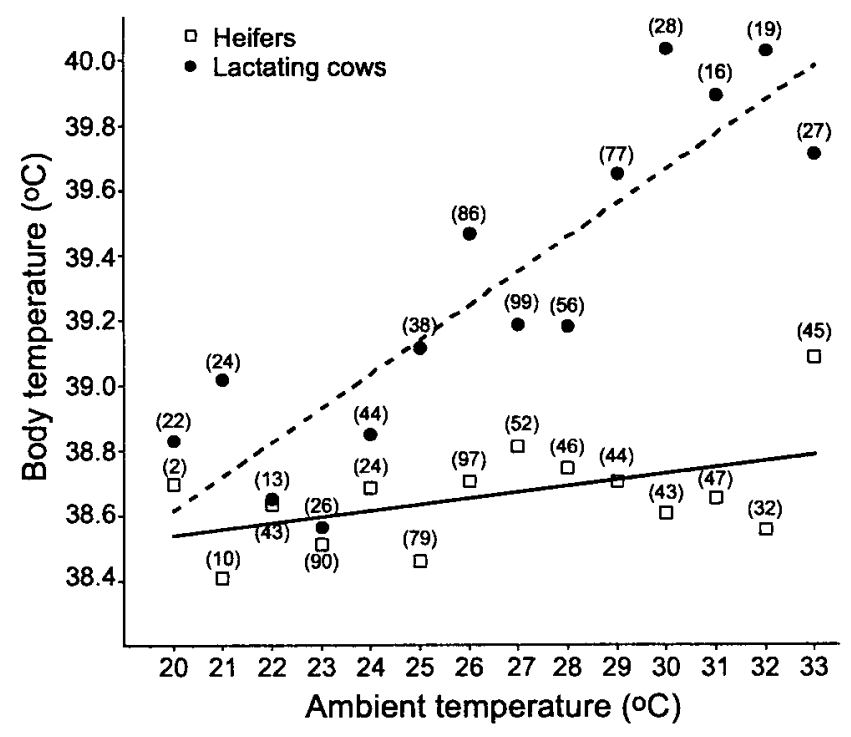

Figure 1. Relationship between ambient temperature (AT) and body temperature (BT) in lactating cows and nulliparous heifers in experiment 1. Values within parentheses represent the number of observations of BT for each group evaluated for each degree of AT. Calculated linear regression for cows was $\mathrm{BT}=0.11 \mathrm{AT}+36.49$ (dashed line) and for heifers was $\mathrm{BT}=0.02 \mathrm{AT}+38.05$ (solid line). than heifers. In addition, $80 \%$ of the UFO from cows had at least one accessory sperm, and on average, UFO had 18 accessory sperm in the zona pellucida (Table 3 ).

\section{Experiment 2}

Body temperatures. During winter, a sample of cows (15 dry cows and 23 lactating cows) was used to assess rectal temperature at the time of embryo collection. Dry cows had a slightly lower $(P<0.05)$ body temperature ( $38.6 \pm 0.07$; ranging from 38.2 to $\left.39.2^{\circ} \mathrm{C}\right)$ than lactating cows $(38.8 \pm 0.04$; ranging from 38.5 to $39.1^{\circ} \mathrm{C}$ ).

Embryo/oocyte collection and evaluation. There were 62 uterine flushings in dry cows and 57 in lactating cows. Recovery rate per flushing was $61.3 \%$ (38/62) and $63.2 \%$ (36/57) for dry and lactating cows, respectively $(P>0.05)$. Recovery rate per CL was not statistically compared between experiments but was numerically greater in experiment 2 than experiment 1 (Table 2 ) and did not differ $(P>0.05)$ between groups in experiment 2 (Table 2). Fertilization rate did not differ $(P>0.05)$ between lactating and dry cows (Table 2). Only four and five UFO were recovered from dry and lactating cows, respectively.

The average quality for embryos recovered from dry cows was greater $(P=0.06)$ than for embryos from lactating cows (Table 2). Figure 3 shows the embryo quality distribution for dry and lactating cows. There were more $(P<0.05)$ degenerate embryos (grade 5$)$ in lactating cows $(42 \%)$ than dry cows (18\%). There was no difference between lactating and dry cows in number of nuclei per embryo, number of nuclei per viable embryo (grades 1,2 , or 3 ) or number of nuclei per nonviable embryo (grades 4 or 5 [Table 2]). Of the flushings that had recovery of at least one structure, there was a greater $(P<0.05)$ percentage with a viable embryo from dry than lactating cows (Table 2). By using embryos as the experimental unit (excluding UFO), there was a greater percentage $(P<0.05)$ of embryos that were viable from dry than from lactating cows (Table 2). Dry and lactating cows had similar numbers of accessory sperm in the embryos (Table 3). There were also few accessory sperm in UFO in experiment 2 (Table 3), and no accessory sperm were found in five of nine of the UFO. 
Table 2. Summary of embryo results from experiments 1 and 2.

\begin{tabular}{|c|c|c|c|c|}
\hline & \multicolumn{2}{|c|}{ Experiment 1 (summer) } & \multicolumn{2}{|c|}{ Experiment 2 (winter) } \\
\hline & Heifers & Lactating cows & Dry cows & Lactating cows \\
\hline $\begin{array}{l}\text { Recovery rate per (CL), \% } \\
\text { [no. embryos or unfertilized oocytes (UFO)/no. CL] }\end{array}$ & $\begin{array}{c}39.5 \\
(32 / 81)\end{array}$ & $\begin{array}{l}30.9 \\
(38 / 123)\end{array}$ & $\begin{array}{l}55.9 \\
(38 / 68)\end{array}$ & $\begin{array}{l}60.3 \\
(41 / 68)\end{array}$ \\
\hline 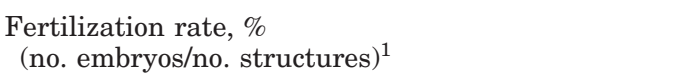 & $\begin{array}{l}100^{\mathrm{b}} \\
(32 / 32)\end{array}$ & $\begin{array}{l}55.3^{\mathrm{a}} \\
(21 / 38)\end{array}$ & $\begin{array}{l}89.5 \\
(34 / 38)\end{array}$ & $\begin{array}{l}87.8 \\
(36 / 41)\end{array}$ \\
\hline $\begin{array}{l}\text { Embryo quality, mean } \pm \text { SEM } \\
\text { Nuclei/embryo, mean } \pm \text { SEM } \\
\text { Flushings with at least one } \\
\text { grade 1-to-3 embryo, } \% \\
\text { (no./no. flushings) }\end{array}$ & $\begin{array}{c}2.2 \pm 0.3^{\mathrm{a}} \\
36.8 \pm 3.0^{\mathrm{b}} \\
71.9^{\mathrm{b}} \\
(23 / 32)\end{array}$ & $\begin{array}{l}3.8 \pm 0.4^{\mathrm{b}} \\
19.3 \pm 3.7^{\mathrm{a}} \\
22.6^{\mathrm{a}} \\
(7 / 31)\end{array}$ & $\begin{array}{l}2.2 \pm 0.3^{\mathrm{c}} \\
30.6 \pm 2.1 \\
72.0^{\mathrm{b}} \\
(26 / 36)\end{array}$ & $\begin{array}{l}3.1 \pm 0.3^{\mathrm{d}} \\
27.2 \pm 2.7 \\
47.0^{\mathrm{a}} \\
(18 / 38)\end{array}$ \\
\hline $\begin{array}{l}\text { Grade 1-to-3 embryos, } \% \\
(\text { no./no. embryos })^{3}\end{array}$ & $\begin{array}{c}71.9^{\mathrm{b}} \\
(23 / 32)\end{array}$ & $\begin{array}{l}33.3^{\mathrm{a}} \\
(7 / 21)\end{array}$ & $\begin{array}{l}82.3^{\mathrm{b}} \\
(28 / 34)\end{array}$ & $\begin{array}{l}52.8^{\mathrm{a}} \\
(19 / 36)\end{array}$ \\
\hline $\begin{array}{l}\text { Nuclei/embryo for grade } 1 \text {-to- } 3 \\
\text { embryos, mean } \pm \text { SEM }\end{array}$ & $41.4 \pm 4.2$ & $37.4 \pm 5.5$ & $33.4 \pm 2.3$ & $32.4 \pm 3.1$ \\
\hline
\end{tabular}

${ }^{\mathrm{a}, \mathrm{b}}$ Different within each row within each experiment; $P<0.05$.

${ }^{\mathrm{c}, \mathrm{d}}$ Different within each row within each experiment; $P=0.06$.

${ }^{1}$ Total number of structures (embryos/UFO) recovered.

${ }^{2}$ Total number of flushings with one or more embryo or UFO recovered.

${ }^{3}$ Total number of embryos recovered.

There was no significant correlation $(P>0.40)$ between circulating $\mathrm{P}_{4}$ and embryo quality in lactating cows, dry cows, or lactating and dry cows together using either the Pearson or Spearman correlation tests. There was also no significant correlation between circulating $\mathrm{P}_{4}$ and number of nuclei per embryo using the Pearson test $(\mathrm{r}=0.09 ; P=0.50)$; however, there was a tendency for a positive correlation $(\mathrm{r}=0.25 ; P=0.06)$ using the Spearman test on the combined data from lactating and dry cows. Figure 4 shows the circulating $\mathrm{P}_{4}$ concentra-

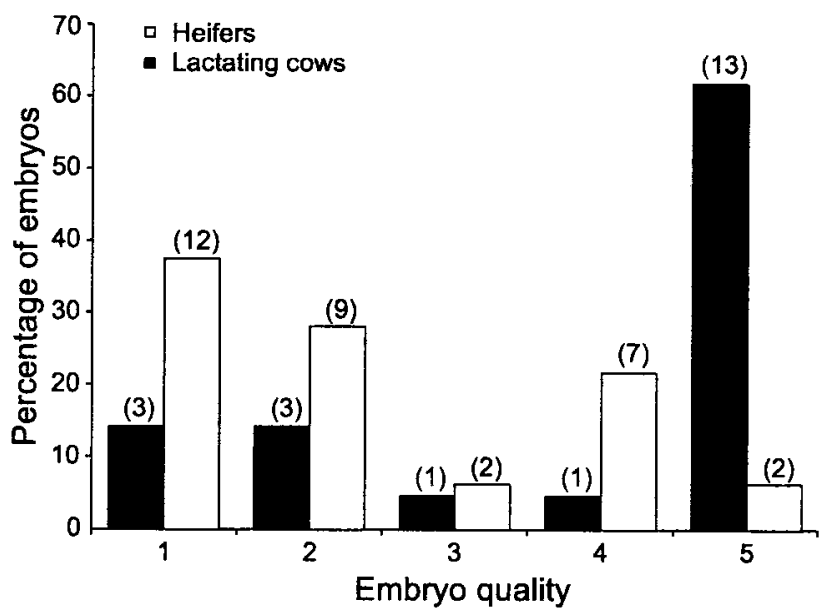

Figure 2. Embryo quality ( $1=$ excellent to $5=$ degenerate $)$ distribution for embryos recovered from lactating cows $(\mathrm{n}=21$ embryos) and nulliparous heifers ( $\mathrm{n}=32$ embryos) in experiment 1 . Values within parentheses represent number of observations. tions in individual lactating and dry cows that were grouped by embryo quality score. Despite a lower percentage of lactating cows with higher-quality embryos, there was no indication that any of the variation in embryo quality score was explained by circulating $\mathrm{P}_{4}$. Similarly, Figure 4 illustrates the lack of relationship between circulating $\mathrm{P}_{4}$ and number of nuclei per embryo in either lactating or dry cows.

\section{DISCUSSION}

The results of this research clearly supported one aspect of our overall hypothesis in that lactating dairy cows had poorer early embryonic development than nonlactating females. Fertilization rate was another important aspect of our hypothesis, and we found that there was a reduction in fertilization rate only during summer in lactating dairy cows. To reduce any potential negative effect due to male fertility problems we used the same high-fertility semen for all breedings in both experiments. Multiple flushings of each animal allowed acquisition of data from most (70\%) experimental animals. The experiments were performed in both summer (experiment 1) and winter (experiment 2), and this allowed comparison of results in the presence or absence of heat stress. Heat stress has been shown to reduce reproductive efficiency, particularly in lactating dairy cows, both by reducing estrous expression/detection and by decreasing CR (Hall et al., 1959; Stevenson et al., 1984; Ryan et al., 1993). An additional technical aspect of the experiments was that an improved technique for 
Table 3. Results (means \pm SEM [median]) for accessory sperm number in the embryos and unfertilized oocytes (UFO) for lactating cows and nulliparous heifers during summer (experiment 1) and for lactating and dry cows during winter (experiment 2).

\begin{tabular}{llllllc}
\hline & \multicolumn{2}{c}{ Experiment 1 (summer) } & & \multicolumn{2}{c}{ Experiment 2 (winter) } \\
\cline { 2 - 3 } \cline { 5 - 6 } & Heifers & Lactating cows & & Dry cows & Lactating cows \\
\hline Accessory sperm no./embryo & $22.4 \pm 5.5^{\mathrm{a}}$ & $37.3 \pm 5.8^{\mathrm{b}}$ & & $36.5 \pm 6.3$ & $42.0 \pm 9.4$ \\
& {$[18.0]$} & {$[30.9]$} & & {$[30.0]$} & {$[31.0]$} \\
Accessory sperm no./UFO & $\cdots$ & $17.8 \pm 12.1$ & & $0.5 \pm 0.5$ & $1.2 \pm 0.6$ \\
& & {$[3.0]$} & & {$[0.0]$} & {$[1.0]$} \\
\hline
\end{tabular}

${ }^{\mathrm{a}, \mathrm{b}}$ Different within each row within each experiment; $P<0.05$.

embryo collection was used in experiment 2 (flushing of entire horn). This appeared nearly to double the embryo/oocyte recovery rates in experiment 2 . It seems unlikely that the differences in recovery rates were due to the season of the year, given that Ryan et al. (1993) previously reported no difference between hot and cool seasons in embryo/oocyte recovery rates on $d 6$ or 7 after estrus (51.6\% and $53.1 \%$, respectively). Thus, the design of these experiments provided important information on the effects of lactation with or without heat stress on fertilization rate and early embryonic development, although it did not allow definitive resolution of the underlying mechanisms. However, it should be noted that experiment 1 has a number of potentially confounding factors that may affect interpretation, such as differing location, diets, and age of animals. Further, comparisons between experiments (seasons) for lactating cows are also subject to confounding by differences in the flushing procedure, the number of days postpartum, and whether or not bST were used.

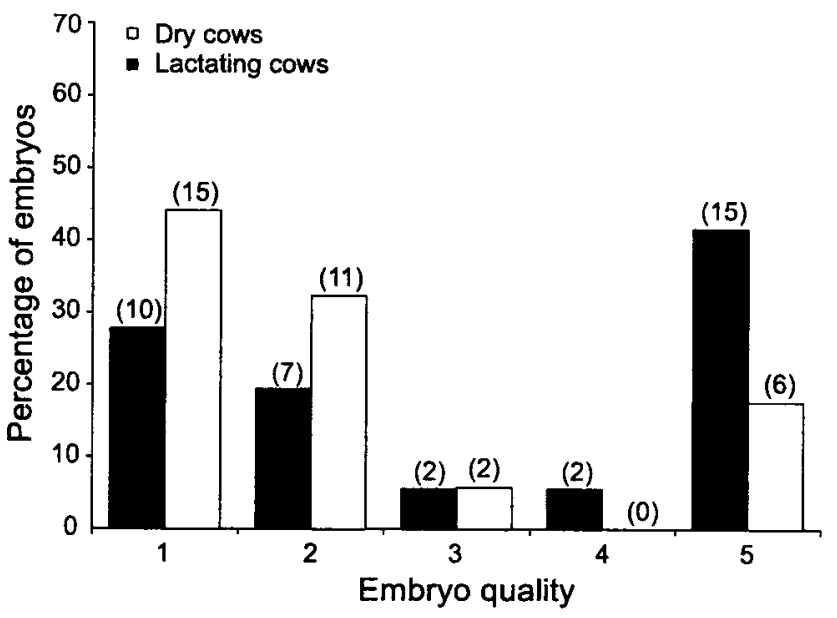

Figure 3. Embryo quality ( $1=$ excellent to $5=$ degenerate $)$ distribution for embryos recovered from lactating cows ( $\mathrm{n}=36$ embryos) and dry cows $(n=34$ embryos) in experiment 2 . Values within parentheses represent number of observations.
Previous studies have reported high fertilization rates after normal ovulation in heifers (Diskin and Sreenann, 1980; Dunne et al., 2000), lactating dairy cows (O'Farrell et al., 1983; Wiebold, 1988; Ryan et al., 1993; Tanabe et al., 1994), beef cows (Ahmad et al., 1995), and after ovulation of a persistent follicle in beef cows (Ahmad et al., 1995). Surprisingly, in experiment 1 we found a substantial reduction in fertilization rate in lactating dairy cows (i.e., $44.7 \%$ of the recovered structures were not fertilized) but not in heifers during the summer. To our knowledge, no previous study has reported a reduction in fertilization rate in normally ovulating cows that were correctly inseminated with high-fertility sperm. The high number of accessory sperm on embryos and UFO that were recovered in this study indicated that sufficient numbers of sperm reached the oocyte. Indeed, we found a significantly greater number of accessory sperm in lactating cows than heifers. This was surprising in light of the larger reproductive tract in cows and the previously reported high positive correlation between embryo quality and number of accessory sperm (DeJarnette et al., 1992). The high accessory sperm numbers observed in this study are similar to results of Nadir et al. (1993), using a large dosage of high quality semen.

The presence of accessory sperm in most UFO in experiment 1 is consistent with fertilization failure being due to an oocyte problem. A number of previous studies are consistent with heat stress decreasing fertilization rate. Rivera and Hansen (2001) found that in vitro exposure of oocytes and sperm to $41^{\circ} \mathrm{C}$ during fertilization reduced the number of embryos that cleaved to two cells. Lenz et al. (1983) found that exposure of oocytes to higher temperatures decreased oocyte maturation and subsequent fertilization. Interestingly, even under the high temperature and humidity encountered in experiment $1,100 \%$ of the recovered structures from virgin heifers were fertilized. This difference between heifers and lactating cows is probably because lactating cows manifested greater increases in body temperature than heifers exposed to similar environ- 

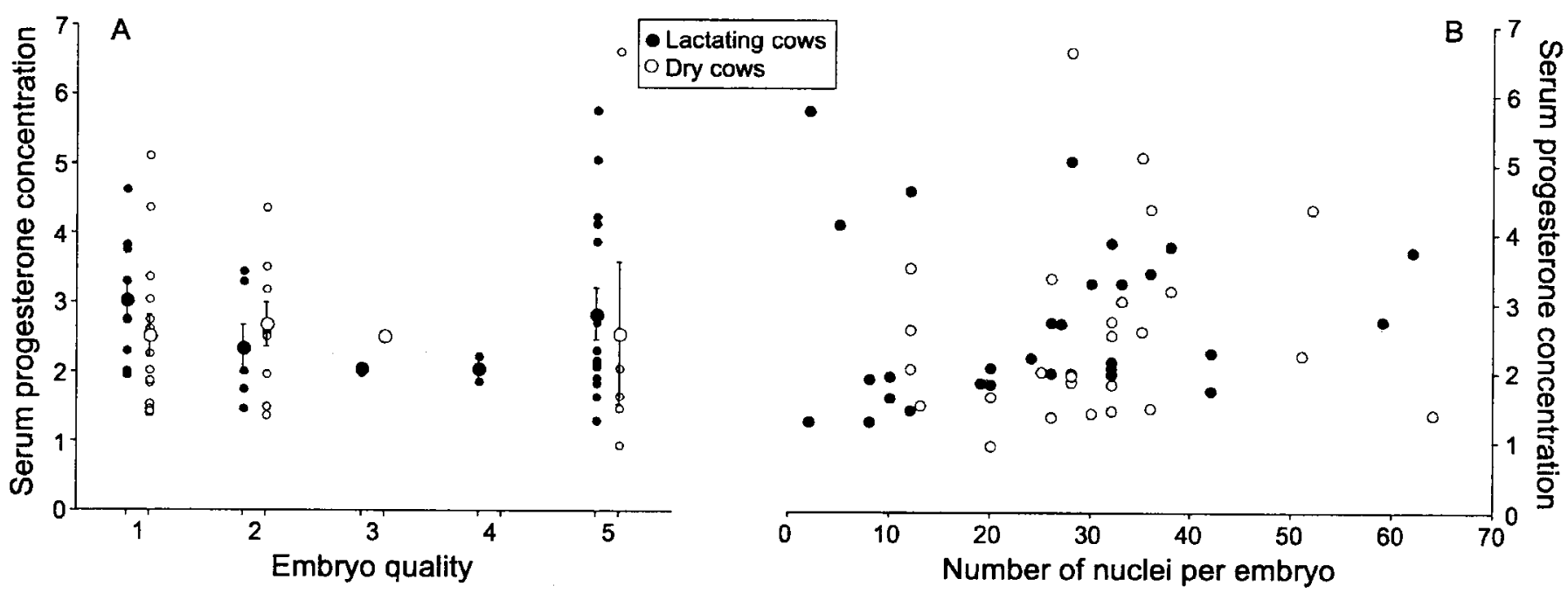

Figure 4. Scatter plot distribution between serum progesterone concentration on d 7 of the estrous cycle and a) embryo quality and b) number of nuclei per embryo on d 6 for lactating and dry cows during experiment 2 .

mental temperatures. The data of Al-Katanani et al. (1999) were also consistent with increased milk yield exacerbating the effects of summer heat stress on fertility. Decreased thermoregulatory ability in lactating cows may be due to the high metabolic energy associated with milk production (Berman et al., 1985). Rocha et al. (1998) reported that oocytes aspirated from Holsteins but not from Brahman cattle exhibited a marked decline in quality and in vitro developmental capacity during heat stress. However, differences in rectal temperatures between the two breeds were not reported. On the other hand, Ryan et al. (1993) reported similar fertilization rates during the hot (84.0\%) and cool $(85.9 \%)$ seasons in lactating Holstein cows, even though the mean rectal temperature was greater in the hot $\left(39.0^{\circ} \mathrm{C}\right)$ than the $\operatorname{cool}\left(38.3^{\circ} \mathrm{C}\right)$ season. Increased fertilization failure in our study may relate to the greater average body temperature in our lactating cows $\left(39.3^{\circ} \mathrm{C}\right)$. In contrast, in experiment 2 , there was a low amount of fertilization failure, indicating that a low fertilization rate may not be the primary cause of infertility in lactating dairy cows during cooler times of the year. However, it should be noted that we attempted to minimize male fertility problems that could produce fertilization failure on commercial dairies, such as low quality semen, inappropriate AI technique, or inappropriate timing of AI.

No previous study has directly compared embryos in high-producing lactating dairy cows to nonlactating cows or heifers. In both experiments of our study, embryo quality was clearly inferior in the lactating cows. The mean embryo quality for heifers (experiment 1 ) or older dry cows (experiment 2) was 2.2 , consistent with high embryo quality reported in previous studies for single-ovulating cows (Diskin and Sreenan, 1980; Ahmad et al., 1995). This result for the dry cows was remarkable, given that many had been culled for reproductive failure in their previous lactations. In contrast, lactating cows had lower average embryo quality with a surprisingly large percentage of embryos as very low quality or degenerate (grade 4 or 5). For example, only one-third of the embryos were viable (grades 1 to 3 ) in experiment 1 , and this percentage excludes almost half of the structures that were designated as UFO. These results differ from those of Ryan et al. (1993), which reported a high percentage of viable embryos in the hot season $(24 / 41=58.5 \%)$ in lactating dairy cows. Ryan et al. (1993) only detected a heat-stress-induced decrease in quality for embryos collected on d 13 or 14 after AI but not for embryos from d 6 or 7 . There could be a number of possible reasons for the difference in results between these two studies, including: embryonic grading system (grades 1 to 4 in their study vs. grades 1 to 5 in our study), sires ( 22 different proven Holstein sires in their study and mixture of sperm from four high fertility sires in our study), or physiology of the cows (milk production, temperature, etc.). In experiment 2, during the cooler time of the year, there appeared to be a higher percentage of viable embryos (52.8\%) among lactating cows than among lactating cows in summer (33.3\%), the summer lactating cows also differing by having received bST and being about $51 \mathrm{~d}$ later postpartum. However, both groups had much lower percentages of viable embryos than did the dry cows in winter (82.3\%). Our low embryonic quality for lactating cows during winter is in accordance with the embryo quality 
reported by Ryan et al. (1993) in the cool season (16/ $31=51.6 \%$ ). Wiebold (1988) also found low embryo quality in lactating dairy cows on $\mathrm{d} 7$ after AI (12 normal of 25 embryos $=48 \%$ ). Other studies that flushed embryos from nonlactating or low-producing dairy cows generally reported high embryo quality (Boyd et al., 1969; O'Farrell et al., 1983).

The mechanisms producing lower embryo quality in lactating dairy cows could be manifold and could not be differentiated with the present experimental design. It is possible that a compromised oocyte may not only have led to decreased fertilization rate, as discussed above, but also may have decreased subsequent embryo quality in fertilized oocytes. Indeed, Ahmad et al. (1995) found that beef cows that ovulated persistent follicles had similar fertilization rates but reduced embryonic development and quality compared to normally ovulating beef cows. Dunne et al. (1999) reported a detrimental effect of elevated energy (two times maintenance requirements) before $\mathrm{AI}$ on embryo survival rate in heifers. This result is consistent with a detrimental effect of elevated feed intake on oocyte quality and subsequent fertility. High feed intake leads to greater steroid metabolism (Wiltbank et al., 2000; Sangsritavong et al., 2002), that can be associated with a reduction in circulating steroids. Studies comparing heifers with lactating cows (Sartori et al., 2000, 2002; Inbar et al., 2001) and dry cows with lactating cows (De La Sota et al., 1993) have reported lower circulating steroid concentrations in lactating than nonlactating females. Reduced embryonic development could also be due to reduced $\mathrm{P}_{4}$ concentrations during the early stages of pregnancy in lactating dairy cows (Ahmad et al., 1996; Mann et al., 1998). However, in the present study, there was no obvious association between circulating $\mathrm{P}_{4}$ and embryo quality or between circulating $\mathrm{P}_{4}$ and number of nuclei per embryo (Figure 4). Regardless of the precise mechanism, provision of high amounts of feed have been found to reduce embryonic development in gilts (Aherne and Kirkwood, 1985), superovulated ewes (McEvoy et al., 1995), and superovulated heifers (O'Callaghan and Boland, 1999; Yaakub et al., 1999). Thus, high milk production was associated with reduced embryo quality by $5 \mathrm{~d}$ after ovulation and possibly related to the high feed intake that occurs in lactating dairy cows. There was an additional detrimental effect of heat stress on embryo quality or cell number, consistent with numerous scientific studies showing reduced in vitro or in vivo embryonic development during heat stress (see literature in Al-Katanani et al., 1999, 2002; Hansen et al., 2001; Rivera and Hansen, 2001).

\section{CONCLUSIONS}

High milk production appears to exert a negative effect on oocyte quality and early embryonic develop- ment that can be detected by $5 \mathrm{~d}$ after ovulation. This detrimental effect is augmented by increased environmental temperature due to pronounced heat stress in lactating cows. Reductions in fertilization rate during heat stress appear to be due to an oocyte problem based on the finding of numerous accessory sperm in the zona pellucida of unfertilized oocytes.

\section{ACKNOWLEDGMENTS}

The authors thank Guilherme J. M. Rosa for his technical assistance with the statistical analyses. We also thank Merial Ltd. for providing GnRH (Cystorelin). This research was supported by Wisconsin State Experiment Station, USDA grant 2000-2276, and the fellowship BEX 1811/97-5 from CAPES of Brazil to Roberto Sartori.

\section{REFERENCES}

Al-Katanani, Y. M., F. F. Paula-Lopes, and P. J. Hansen. 2002. Effect of season and exposure to heat stress on oocyte competence in Holstein cows. J. Dairy Sci. 85:390-396.

Al-Katanani, Y. M., D. W. Webb, and P. J. Hansen. 1999. Factors affecting seasonal variation in 90-day nonreturn rate to first service in lactating Holstein cows in a hot climate. J. Dairy Sci. 82:2611-2616.

Aherne, F. X., and R. N. Kirkwood. 1985. Nutrition and sow prolificacy. J. Reprod. Fertil. (Suppl. 33):169-183.

Ahmad, N., S. W. Beam, W. R. Butler, D. R. Deaver, R. T. Duby, D. R. Elder, J. E. Fortune, L. C. Griel, L. S. Jones, R. A. Milvae, J. L. Pate, I. Revah, D. T. Schreiber, D. H. Townson, P. C. W. Tsang, and E. K. Inskeep. 1996. Relationship of fertility to patterns of ovarian follicular development and associated hormonal profiles in dairy cows and heifers. J. Anim. Sci. 74:1943-1952.

Ahmad, N., F. N. Schrick, R. L. Butcher, and E. K. Inskeep. 1995. Effect of persistent follicles on early embryonic losses in beef cows. Biol. Reprod. 52:1129-1135.

Barret, G. R., and L. E. Casida. 1946. Time of insemination and conception rates in artificial breeding. J. Dairy Sci. 29:556.(Abstr.).

Beam, S. W. 1995. Follicular development in postpartum dairy cattle: Effects of energy balance and dietary lipid. Ph.D. Diss., Cornell Univ., Cornell, NY.

Berman, A., Y. Folman, M. Kaim, M. Mamen, Z. Herz, D. Wolfenson, A. Arieli, and Y. Graber. 1985. Upper critical temperatures and forced ventilation effects for high-yielding dairy cows in a subtropical climate. J. Dairy Sci. 68:1488-1495.

Boyd, J., P. Bacsich, A. Young, and J. A. McCracken. 1969. Fertilization and embryonic losses in dairy cattle. Br. Vet. J. 125:87-97.

Butler, W. R. 1998. Review: Effect of protein nutrition on ovarian and uterine physiology in dairy cattle. J. Dairy Sci. 81:2533-2539.

Casida, L. E. 1961. Present status of the repeat-breeder cow problem. J. Dairy Sci. 44:2323-2329.

De La Sota, R. L., M. C. Lucy, C. R. Staples, and W. W. Thatcher. 1993. Effects of recombinant bovine somatotropin (Sometribove) on ovarian function in lactating and nonlactating dairy cows. J. Dairy Sci. 76:1002-1013.

DeJarnette, J. M., R. G. Saacke, J. Bame, and C. J. Vogler. 1992. Accessory sperm: Their importance to fertility and embryo quality, and attempts to alter their number in artificially inseminated cattle. J. Anim. Sci. 70:484-491.

Diskin, M. G., and J. M. Sreenan. 1980. Fertilization and embryonic mortality rates in beef heifers after artificial insemination. J. Reprod. Fertil. 59:463-468. 
Dunne, L. D., M. G. Diskin, M. P. Boland, K. J. O’Farrell, and J. M. Sreenan. 1999. The effect of pre- and post-insemination plane of nutrition on embryo survival in beef heifers. Anim. Sci. 69:411-417.

Dunne, L. D., M. G. Diskin, and J. M. Sreenan. 2000. Embryo and foetal loss in beef heifers between day 14 of gestation and full term. Anim. Reprod. Sci. 58:39-44.

Elsden, R. P., J. F. Hasler, and G. E. Seidel, Jr. 1976. Nonsurgical recovery of bovine eggs. Theriogenology 6:523-532.

Faust, M. A., B. T. McDaniel, O. W. Robison, and J. H. Britt. 1988. Environmental and yield effects on reproduction in primiparous Holsteins. J. Dairy Sci. 71:3092-3099.

Foote, R. H. 1975. Estrus detection and estrus detection aids. J. Dairy Sci. 58:248-256.

Hall, J. G., C. Branton, and E. J. Stone. 1959. Estrus, estrous cycles, ovulation time, time of service, and fertility of dairy cattle in Louisiana. J. Dairy Sci. 42:1086-1094.

Hansen, P. J., M. Drost, R. M. Rivera, F. F. Paula-Lopes, Y. M. AlKatanani, C. E. Krininger, and C. C. Chase. 2001. Adverse impact of heat stress on embryo production: Causes and strategies for mitigation. Theriogenology 55:91-103.

Inbar, G., D. Wolfenson, Z. Roth, M. Kaim, A. Block, and R. BrawTal. 2001. Follicular dynamics and concentrations of steroids and gonadotropins in lactating cows and nulliparous heifers. J. Dairy Sci. 84(Suppl. 1):465.(Abstr.).

Lenz, R. W., G. D. Ball, M. L. Leibfried, R. L. Ax, and N. L. First. 1983. In vitro maturation and fertilization of bovine oocytes are temperature-dependent processes. Biol. Reprod. 29:173-179.

Littell, R. C., G. A. Milliken, W. W. Stroup, and R. D. Wolfinger. SAS System for Mixed Models. SAS Inst. Inc., Cary, NC.

Lucy, M. C. 2001. Reproductive loss in high-producing dairy cattle: Where will it end? J. Dairy Sci. 84:1277-1293.

Macmillan, K. L., and J. D. Watson. 1975. Fertility diferences between groups of sires relative to the stage of oestrus at the time of insemination. Anim. Prod. 21:243-249.

Mann, G. E., G. E. Lamming, R. S. Robinson, and D. C. Wathes. 1998. The regulation of interferon- $\tau$ production and uterine hormone receptors during early pregnancy. J. Reprod. Fertil. 54(Suppl.):317-328.

Mares, S. E., A. C. Menge, W. J. Tyler, and L. E. Casida. 1961. Genetic factors affecting conception rate and early pregnancy loss in Holstein cattle. J. Dairy Sci. 44:96-103.

McEvoy, T. G., J. J. Robinson, R. P. Aitken, P. A. Findlay, R. M. Palmer, and I. S. Robertson. 1995. Dietary-induced suppression of pre-ovulatory progesterone concentrations in superovulated ewes impairs the subsequent in vivo and in vitro development of their ova. Anim. Reprod. Sci. 39:89-107.

Nadir, S., R. G. Saacke, J. Bame, J. Mullins, and S. Degelos. 1993. Effect of freezing semen and dosage of sperm on number of accessory sperm, fertility, and embryo quality in artificially inseminated cattle. J. Anim. Sci. 71:199-204.

O'Callaghan, D., and M. P. Boland. 1999. Nutritional effects on ovulation, embryo development and the establishment of pregnancy in ruminants. Animal Science 68:299-314.

O'Farrell, K. J., O. H. Langley, P. J. Hartigan, and J. M. Sreenan. 1983. Fertilization and embryonic survival rates in dairy cows culled as repeat breeders. Vet. Rec. 112:95-97.

Pursley, J. R., M. R. Kosorok, and M. C. Wiltbank. 1997a. Reproductive management of lactating dairy cows using synchronization of ovulation. J. Dairy Sci. 80:301-306.

Pursley, J. R., M. C. Wiltbank, J. S. Stevenson, J. S. Ottobre, H. A. Garverick, and L. L. Anderson. 1997b. Pregnancy rates per artificial insemination for cows and heifers inseminated at a synchronized ovulation or synchronized estrus. J. Dairy Sci. 80:295-300.

Rivera, R. M., and P. J. Hansen. 2001. Development of cultured bovine embryos after exposure to high temperatures in the physiological range. Reproduction 121:107-115.
Rocha, A., R. D. Randel, J. R. Broussard, J. M. Lim, R. M. Blair, J. D. Roussel, R. A. Godke, and W. Hansel. 1998. High environmental temperature and humidity decrease oocyte quality in Bos taurus but not Bos indicus cows. Theriogenology 49:657-665.

Rowe, R. F., M. R. Del-Campo, C. L. Eilts, L. R. French, R. P. Winch, and O. J. Ginther. 1976. A single cannula technique for nonsurgical collection of ova from cattle. Theriogenology 6:471-483.

Royal, M. D., A. O. Darwash, A. P. F. Flint, R. Webb, J. A. Woolliams, and G. E. Lamming. 2000a. Declining fertility in dairy cattle: Changes in traditional and endocrine parameters of fertility. Anim. Sci. 70:487-501.

Royal, M. D., G. E. Mann, and A. P. F. Flint. 2000b. Strategies for reversing the trend towards subfertility in dairy cattle. Vet. J. 160:53-60.

Ryan, D. P., J. F. Prichard, E. Kopel, and R. A. Godke. 1993. Comparing early embryo mortality in dairy cows during hot and cool seasons of the year. Theriogenology 39:719-737.

Sangsritavong, S., D. K. Combs, R. Sartori, and M. C. Wiltbank. 2002. High feed intake increases blood flow and metabolism of progesterone and estradiol- $17 \beta$ in dairy cattle. J. Dairy Sci. 85:2831-2842.

Sartori, R., J. Haughian, G. J. M. Rosa, R. D. Shaver, and M. C. Wiltbank. 2000. Differences between lactating cows and nulliparous heifers in follicular dynamics, luteal growth, and serum steroid concentrations. J. Dairy Sci. 83(Suppl. 1):212.(Abstr.).

Sartori, R., G. J. M. Rosa, and M. C. Wiltbank. 2002. Ovarian structures and circulating steroids in heifers and lactating cows in summer and lactating and dry cows in winter. J. Dairy Sci. 85:2813-2822.

Schmitt, E. J., T. Diaz, M. Drost, and W. W. Thatcher. 1996. Use of a gonadotropin-releasing hormone agonist or human chorionic gonadotropin for timed insemination in cattle. J. Anim. Sci. 74:1084-1091.

Silvia, W. J. 1998. Changes in reproductive performance of Holstein dairy cows in Kentucky from 1972 to 1996. J. Dairy Sci. 81(Suppl.1):244.(Abstr.)

Spalding, R. W., R. W. Everett, and R. H. Foote. 1975. Fertility in New York artificially inseminated Holstein herds in Dairy Herd Improvement. J. Dairy Sci. 58:718-723.

Stevenson, J. S., M. K. Schmidt, and E. P. Call. 1984. Stage of estrous cycle, time of insemination, and seasonal effects on estrus and fertility of Holstein heifers after prostaglandin $\mathrm{F}_{2 \alpha}$. J. Dairy Sci. 67:1798-1805.

Tanabe, T. Y., D. R. Deaver, and H. W. Hawk. 1994. Effect of gonadotropin-releasing hormone on estrus, ovulation and ovum cleavage rates of dairy cows. J. Anim. Sci. 72:719-724.

United States Department of Agriculture (USDA). 2001. Milk production, disposition and income-suppl. (PMB-BB). http://usda.mannlib.cornell.edu/reports/nassr/dairy/pmppbbm/. Accessed Oct. $28,2001$.

United States Department of Agriculture (USDA); Economics, Statistics and Cooperatives Service. 1978. Dairy Situation (DS-369). United States Government Printing Office, Washington, DC.

Washburn, S. P., W. J. Silvia, C. H. Brown, B. T. McDaniel, and A. J. McAllister. 2002. Trends in reproductive performance in southeastern Holstein and Jersey DHI herds. J. Dairy Sci. 85:244-251.

Wiebold, J. L. 1988. Embryonic mortality and the uterine environment in first-service lactating dairy cows. J. Reprod. Fert. 84:393-399.

Wiltbank, M. C., P. M. Fricke, S. Sangsritavong, R. Sartori, and O. J. Ginther. 2000. Mechanisms that prevent and produce double ovulations in dairy cattle J. Dairy Sci. 83:2998-3007.

Yaakub, H., D. O'Callaghan, and M. P. Boland. 1999. Effect of type and quantity of concentrates on superovulation and embryo yield in beef heifers. Theriogenology 51:1259-1266.

Zar, J. H. 1996. Biostatistical Analysis. 3rd ed. Prentice Hall, Upper Saddle River, NJ. 